JURNAL HUMANIORA

TEKNOLOGI

Vol. 1 No.1 ; Oktober 2015

\title{
AN ANALYSIS OF STUDENTS' ABILITY IN CONSTRUCTING SIMPLE PRESENT TENSE SENTENCES(A CASE STUDY AT THE STATE JUNIOR HIGH SCHOOL (SMP NEGERI 2) HAMPARAN PERAK)
}

\author{
YULIANA NINGSIH \\ Department of Mechanical Engineering, The State Polytechnic of Tanah Laut \\ Jalan A. Yani KM. 6 Pelaihari Kab. Tanah Laut, South Kalimantan \\ e-mail : yuliea585@gmail.com
}

\begin{abstract}
The research deals with students' ability in constructing Simple Present Tense and it is objected to see whether the students are able to use Simple Present Tense.

This research was conducted at the third grade of State Junior High School (SMPN 2) Hamparan Perak Kabupaten Deli Serdang. From 60 students of the total sample were selected randomly. The data was obtained by administering a test related to Simple Present Tense. This study was conducted in quantitative approach with the standard ability for an individual mastery of learning is minimum $70 \%$ of the test given and that is suggested by Tinambunan (1980) which is divided in to five levels of ability namely: out standing ability $(A)$, above ability $(B)$, average ability $(C)$, below average ability $(D)$, and insufficient ability (E) with each level represents different percentage.

Thepopulation of this research was the third year students of SMPN 2 Hamparan PerakKabupaten Deli Serdang. The total number of the population was 119 students. There are three classes; III.1, III.2, and III.3. The researcher used simple random sampling to select the sample.

The result shows that the students' ability in constructing Simple Present Tense is very low as there was no student in the levels out standing ability, above average ability, and average ability. There were 6 students in the level of below average ability (10\%) and 54 students in the level of insufficient ability (90\%).
\end{abstract}

Keywordsi : ability, Simple Present Tense, sentences

\section{INTRODUCTION}

English is a language which is used in the world as a second and foreign language. Nowadays, English has been taught in the third year student of the English Elementary School until Senior High School. So, the ministry of National Education prescribes the English subject. The users of the language are constantly uttering new sentences that they have never heard before. Most students are English as a foreign language with the purpose of 
the ability to communicate and to construct sentence.Hornby (1955:662) states that "Language is the system of sounds and words used by humans to express their thoughts and feelings". It means that language is a means of communication is a central fact of human existence and social process. By using language, they can express their own needs, wants attitudes and their language.

According to Wren and Martin (1990:77): "The word 'tense' comes from the Latin 'tempus' means 'time'. A verb that refers to Present Time is said to be in the Present Tense. The researcher thinks that using the Present Tense is a basic knowledge to Master English. This research focuses in the Simple Present Tense, especially the researcher wants to know students' abilityin constructing Simple Present Tense sentences. If the students can not understand how to construct Simple Present Tense sentences well, they will find a lot of difficulties to build and to analyze their kinds of sentences on the higher levels. And Grammar is one of the important topics that can combine the form of words into sentence and should follow the rule of good sentences. Thus, Grammar is the study of rules governing the use of language and it is part of the general study of language. So, grammar deals with the structure of a sentence, its aim is to develop the students to use English correctly and to construct sentence.

In this study, the researcher interest to find out the problem that have the influence the ability in writing, but in simple ways. Besides that, the researcher wants to know the best ability in writing. It is very useful to restrain some problems above and the researcher finds out the State Junior High School that has these problems.

\section{METHODOLOGY}

This study is based on the descriptive quantitative method. It is used as suggested by Nawawi and Martin (1994). This study is one variable research and it applies the descriptive statistics which is focuses on finding without making any manipulations.

The population of the research was the third year students of SMP NegeriHamparan Perak, TandamHilir II kabupaten Deli Serdang. There are eleven classes in the school, and the population of the research was 119 students in thisthird year of SMP Negeri 2 that divided into three classes. The number of the students was 119 from three parallel classes. The detail is as follows: 


\section{Population}

Table 1:

\begin{tabular}{|c|c|}
\hline Class & Population \\
\hline III.1 & 38 \\
III.2 & 40 \\
III.3 & 41 \\
\hline
\end{tabular}

The sample is 60 students. It was drawn by using simple random sampling (Suhendi, 2004: 25). From the total amount of the classes, the 60 students of the third year classes were used as sample.

The data for the study is obtained by administering a multiple choice test and sentences building test as the instrument. The test consists of 20 items multiple choice and 10 items sentences building test. In this research of the test is used as the supporting data.

The data of the students' ability will be analyzed. The score of the correct answer are classified into three groups. High (70-100), medium (60-69), low (0-59). It is stated that the standard ability for individual is more than $75 \%$ correct on the test given. Furthermore, it can be stated that if:

1. $50 \%$ or more of the sample get $75 \%$ or more correct on the test, the students can be categorized as able.

2. Less that $50 \%$ of the sample get $75 \%$ correct, they can be categorized as unable.

To see the students' ability in detail, the following criteria devised by Tinambunan (1998) wil be used.

Table 2:

Level of Students' Ability

\begin{tabular}{|l|l|l|}
\hline Percentage of Correct & Grade & Level of Ability \\
\hline $93-100$ Percent Correct & A - Out Standing & Out Standing Ability \\
$85-92$ Percent Correct & B - Very Good & Above Average Ability \\
$75-84$ Percent Correct & C - Satisfactory & Average Ability \\
$60-74$ Percent Correct & D - Very Weak & Below Average Ability \\
Below 60 Percent Correct & E - Fail & Insufficient Ability \\
\hline
\end{tabular}




\section{FINDINGS AND DISCUSSIONS}

The data for this study were obtained by administering the test to sample. It was a set of scores of students' ability in constructing Simple Present Tense sentences. The test consisted of 30 items and the maximum score of the test was 20. In scoring the test, each of the correct answer was scored 1 and the wrong answer 0 . In detail, the data can be presented as follows:

1. The number of the students examined is 60 .

2. The total score of the student is 626 .

3. The minimum score is 2 .

4. The maximum score is 20 .

5. The range is 18 .

6. The mean is 10.43

7. The standard deviation is 4.90

Table 3:

Mean Scores and Standard Deviation of Students' Ability in Constructing Simple Present Tense Sentences

\begin{tabular}{|l|c|c|c|c|c|c|c|}
\hline & N & Range & Min. & Max. & Sum & Mean & $\begin{array}{c}\text { Standard } \\
\text { Deviation }\end{array}$ \\
\hline $\begin{array}{l}\text { Scores } \\
\text { Valid N } \\
\text { (listwise) }\end{array}$ & 60 & 18 & 2 & 20 & 626 & 10,43 & 4,90 \\
\hline
\end{tabular}

The table above shows that from 60 students that were used as respondents, the range scores is 18; that is by substracting the highest score to the lowest score. From 60 respondents, the minimum score or the lowest score is 2 and the maximum score or the highest score is 20. So, from 60 respondents the mean or the average score that the respondents obtained was 10.43 . The mean were calculated by dividing the total score 626 with the total number of the students. The last is standard deviation. It is the square of the sum of deviation square two of group of figures divided into the amount of figures. Standard deviation calculation in the table above shows the standard measurement dispersion for the data, and it should be 4.90 . 
The following information will give more detail information about the data in the table in the previous page:

1. One student get score 2 .

2. Three students get score 3 .

3. Two students get score 4 .

4. Seven students get score 5 .

5. One student get score 6 .

6. Five students get score 7.

7. Four students get score 8 .

8. Six students get score 9 .

9. Four students get score 10 .

10. Two students get score 11 .

11. Five students get score 12 .

12. Four students get score 13 .

13. Five students get score 15 .

14. Four students get score 16.

15. One student get score 17 .

16. Two students get score 18 .

17. One student get score 19.

18. Three students get score 20 .

Based on the previous data, it can be seen there is 1 student who gets 2 , the lowest score, or it is only $1.7 \%$ and there are 3 students get 20 , the highest score with percentage $5 \%$. It means that no students reach $75 \%$ of the correct answer based on standard ability, the students can only below $75 \%$ of the test correctly.

As stated before, the data is analyzed by applying criteria devised in Curriculum and Instruction System of Development Procedure (1994) and Tinambunan's (1998; 29) related to the students' ability in constructing Simple present tense Sentences, it is illustrated as follows: 
Table 4:

Students' Correct Percentage

\begin{tabular}{|l|c|c|c|c|}
\hline No & Criteria & Students' Correct (x) & $\begin{array}{c}\text { Percetage of Correct } \\
\text { (PC) }\end{array}$ & Ability \\
\hline 1 & $>75 \%$ & 0 & $0 \%$ & Able \\
\hline 2 & $<75 \%$ & 60 & $100 \%$ & Unable \\
\hline 3 & $\sum$ & 60 & $100 \%$ & \\
\hline
\end{tabular}

From the table above, the students whose correct answer is higher than $75 \%$ was 0 with percentage of $0 \%$. Those correct answers are lower than $75 \%$ with percentage of $100 \%$. It can be concluded that all the students could not answer the test in a good percentage.

The data were analyzed by applying criteria devised in Curriculum 994 and the nstructional System of development Procedure and by Tinambunan (1988) related to the students' abilitity in significant. It is illustrated s follows:

Table 5:

Students' Ability in Significant

\begin{tabular}{|c|c|c|c|}
\hline No & Students (x) & Grade & Percentage \\
\hline 1 & 0 & A & $0 \%$ \\
\hline 2 & 0 & B & $0 \%$ \\
\hline 3 & 0 & C & $0 \%$ \\
\hline 4 & 6 & D & $10 \%$ \\
\hline 5 & 54 & E & $90 \%$ \\
\hline
\end{tabular}

It can be seen from the table above that there is nt students in the level of out standing ability (A), above average ability (B), and average ability (C). It means that percentage of them $0 \%$. Six students are in the level of below average ability (D) or $10 \%$ and 54 students in the level of insufficient ability (E) or $90 \%$.

During the administration of the test, the students got difficulties to use Simple Present Tense. Most of students had problem with grammar and vocabulary, besides that they could not do the test in part II, sentences building test. 
For example:

- Jackson - to - comes - on - work - Monday - always - Mr.

The correct one is: "Mr Jackson always comes to work on Monday."

They answered incorrect sentences. It means that most of the third year students at SMP Negeri 2 hamparan Perak are unable on the data obtained to construct Simple Present tense Sentences, since there are less than $50 \%$ or fifty six students can answer $75 \%$ questions of the test given.

In addition, they also lacked in mastering grammar. It was difficult for them to understand this subject. For this reason, most of the students faced some difficulties to construct Simple Present Tense Sentences.Additionally the students' failure to construct Simple Present Tense sentences was caused by several aspects namely structure problem, misinterpretation, and reference mastery. Besides, most of students do not take an English Course outside the school time that it can not add or improve their skill as well as their knowledge in English especially construct Simple Present tense sentences.

This study hopefully can enrich students' knowledge about Simple Present Tense and they are hoped to be able to use in their life and daily communication.

\section{CONCLUSIONS AND SUGGESTIONS}

There are some points to be drawn as the conclusion based on the previous data:

1. The third class students of SMP Negeri 2 Hamparan Perak KabupatenDeli Serdang are undoubtedly unable to construct Simple Present Tense correctly since there is none of the sample can get $75 \%$ correct answer on the test or less than $50 \%$ from the whole sample.

2. The degree of students' ability to construct Simple Present Tense is very low since there is no students in the level out standing ability (A), above average ability (B), and average ability (C). Only 6 students in the level below average ability (D), it means that 6 students with percentage of $10 \%$. There are 54 students in the level insufficient ability (E), it means they could answer less than $60 \%$ correctly of the test with percentage of $90 \%$.

The skill to build good sentences is necessary for students who learn English as their major subject. It is needed to face the globalization. It means that the students should master English well in order to have a good job. Besides that there are some suggestions as follows: 
1. The students must follow the course English in order to it can improve their knowledge about English especially Simple Present Tense. But they should have high motivation to master English. So, they are suggested to revise their lessons at home. Besides that, they should also find the materials from other sources of information, for example they can read books in the library or they can find more information from the internet. It means that they must go out from their village because it is so far from their village or house to the city.

2. All English teachers give special attention to the students chiefly of their subject related to grammar. And they to be more familiar with the students to develop and to empower the students about grammar especially Simple Present tense.

3. The school should have good facilities for all the students in order to improve their ability in English such as providing more books in the library related to English especially to Grammar or conducting an extra English class in school.

4. It is suggested to other researchers to conduct research dealing both with ability and Simple Present Tense or other topics in grammar in other schools.

\section{ACKNOWLEDGEMENTS}

The writer would like to express her deep gratitude and appreciation to Drs. SihabuddinChalid, M.M.Pdas the director of the State Polytechnic of Tanah Laut, South Kalimantan; all of the lecturers in the State Polytechnic of Tanah Laut, South Kalimantan;

Prof. DR. H. EfendiBarus, MA; and the last, the Headmaster andteachers in SMP Negeri 2 Hamparan Perak.

\section{REFERENCES}

Azar, Betty Schampfer. 1989. Understanding and Using English Grammar. New Jersey; Prentice Hall Inc.

Byrne, D. 1979. Teaching Writing Skill. London: Longman.

Cobuild, Collins. 1995. English Grammar. New Delhi: Collins BLT.

Echols, J anHasan Shadily. 1990. KamusInggris Indonesia. Jakarta: Grammedia. Frank, Marcell. 1972. Modern English. New Jersey: Prentice Hall.

Hornby, A.S. 1955. Oxford Advanced Learner's Dictionary of Current English. London: Oxford University. 
Manser, M.H. 1995.Oxford Learner's Pocket Dictionary. New York: Oxford University Press.

Nawawi and Martin. 1994. PengantarPenelitianPendidikan. Jakarta: Depdikbud.

Suhendi, Andang. 2004. MetodePenelitian. Medan: UISU.

Syah, D and EnongAzimar. 1997. Modern English Grammar. Jakarta: Simpplex. 